\title{
Rice Bran as Source for the Synthesis of Imidazoline-type Inhibitors: Synthesis and Corrosion Performance
}

\author{
E. Reyes-Dorantes ${ }^{1,2}$, J. Zúñiga-Díaz ${ }^{1,2}$, A. Quinto-Hernández ${ }^{1}$, J. Porcayo-Calderon $^{2,3 *}$, \\ J.G. Gonzalez-Rodriguez, G.K. Pedraza-Basulto ${ }^{4}$, L. Martínez-Gomez, ${ }^{2,5}$ \\ ${ }^{1}$ Tecnológico Nacional de México - Instituto Tecnológico de Zacatepec, Calzada Instituto Tecnológico \\ 27, 62780 Zacatepec, MOR, México \\ ${ }^{2}$ Instituto de Ciencias Físicas, Universidad Nacional Autónoma de México, Avenida Universidad s/n, \\ 62210 Cuernavaca, MOR, México. \\ ${ }^{3}$ CIICAp, Universidad Autónoma del Estado de Morelos, Avenida Universidad 1001, 62209 \\ Cuernavaca, MOR, México. \\ ${ }^{4}$ Facultad de Ingeniería, UNACAR, C.P. 24180, Ciudad del Carmen, CAM, Mexico. \\ ${ }^{5}$ Corrosion y Protección (CyP), Buffon 46, 11590 México City, DF, México. \\ *E-mail: jporcayoc@gmail.com
}

doi: $10.20964 / 2018.01 .19$

Received: 7 September 2017 / Accepted: 26 October 2017 / Online Published: 1 December 2017

\begin{abstract}
Based on its high oil content, this research proposes the use of an agro-industrial by-product (rice bran) as a sustainable option for the synthesis of environmentally friendly corrosion inhibitors. The extraction and characterization of the raw rice bran oil was carried out, and the imidazoline-type inhibitors were synthesized from a 1:3 molar ratio (oil:aminoethylethanolamine). The corrosion inhibitory capacity of the product obtained was evaluated by electrochemical techniques such as potentiodynamic polarization curves and real-time corrosion monitoring. The inhibitory capacity of the synthesized compound was evaluated on an API X-70 steel using a saline solution (3.5\% wt. $\mathrm{NaCl})$ saturated with $\mathrm{CO}_{2}$. The evaluation was performed at three temperatures $\left(30,50\right.$ and $\left.70{ }^{\circ} \mathrm{C}\right)$ and different concentrations of inhibitor $(0,5,10,25,50$ and $100 \mathrm{ppm})$. The results showed that the sustainable use of agro-industrial by-products is a good alternative for the synthesis of environmentally friendly corrosion inhibitors with high inhibition efficiencies.
\end{abstract}

Keywords: Green inhibitor, Rice Bran, Raw Oil, $\mathrm{CO}_{2}$ corrosion, Imidazoline.

\section{$\underline{\text { FULL TEXT }}$}

(C) 2018 The Authors. Published by ESG (www.electrochemsci.org). This article is an open access article distributed under the terms and conditions of the Creative Commons Attribution license (http://creativecommons.org/licenses/by/4.0/). 